\title{
PENGARUH BUDAYA ORGANISASI, KOMPETENSI PEGAWAI DAN AKUNTABILITAS KINERJA TERHADAP KINERJA SKPD DI KABUPATEN TABALONG
}

\author{
Agus Sugiarto \\ Sekolah Tinggi Ilmu Ekonomi Pancasetia \\ Jl. Ahmad Yani Km. 5.5 Banjarmasin \\ agusrasyad@gmail.com
}

\begin{abstract}
Abstrak : Penelitian ini bertujuan untuk mengetahui : (1) Pengaruh budaya organisasi terhadap kinerja SKPD, (2) Pengaruh kompetensi pegawai terhadap kinerja SKPD, (3) Pengaruh akuntabilitas kinerja terhadap kinerja SKPD, (4) Pengaruh budaya organisasi, kompetensi pegawai dan akuntabilitas kinerja berpengaruh simultan terhadap kinerja pada SKPD, (5) Pengaruh budaya organisasi, kompetensi pegawai dan akuntabilitas kinerja mana yang berpengaruh dominan terhadap kinerja pada SKPD di Kabupaten Tabalong tahun 2019. Penelitian ini merupakan penelitian diskriptif dengan pendekatan kuantitatif. Pengumpulan data kuantitatif dilakukan ini menggunakan metode survei dengan cara menggunakan instrumen kuesioner. Lokasi penelitian di Kabupaten Tabalong pada 9 SKPD yang telah dilakukan evaluasi SAKIP. Hasil penelitian menunjukkan bahwa : (1) Budaya organisasi, kompetensi pegawai dan akuntabilitas kinerja mempunyai pengaruh positif dan signifikan terhadap kinerja SKPD lingkup SKPD di Pemda Kabupaten Tabalong, (2) Kompetensi pegawai mempunyai pengaruh yang paling dominan terhadap kinerja SKPD dibandingkan dengan pengaruh budaya organisasi dan akuntabilitas kinerja di Pemda Kabupaten Tabalong
\end{abstract}

Kata Kunci : Budaya Organisasi, Kompetensi, Akuntabilitas, Kinerja.

\section{Latar Belakang}

Perbaikan Governance dan sistem manajamen merupakan agenda penting dalam reformasi pemerintahan yang sedang dijalankan oleh pemerintah. Sistem pemerintahan yang berfokus pada peningkatan akuntabilitas dan sekaligus peningkatan kinerja yang berorientasi pada hasil (outcome) dikenal sebagai Sistem Akuntabilitas Kinerja Instansi Pemerintah (SAKIP) sebagaimana dimaksud dalam Peraturan Presiden Nomor 29 tahun 2014. SAKIP diimplementasikan secara self assesment oleh masing-masing Instansi Pemerintah.Hal ini berarti Instansi pemerintah secara mandiri harus merencanakan, melaksanakan, mengukur dan memantau kinerja serta melaporkannya kepada Instansi yang lebih tinggi. Pelaksanaan sistem dengan mekanisme tersebut memerlukan evaluasi dari pihak yang lebih independen agar diperoleh umpan balik yang obyektif untuk meningkatkan Akuntabilitas dan Kinerja instansi pemerintah agar secara konsisten meningkatkan implementasi SAKIP-nya dan mewujudkan capaian kinerja sesuai dengan yang diamanahkan dalam RPJMN dan RPJMD.

Untuk mewujudkan tujuan dari pemerintah itu sendiri diperlukan organisasi pemerintahan yang berlangsung secara tertib dengan ditandai adanya pengaturan, pembagian tugas, cara kerja dan hubungan antara pekerjaan yang satu dengan pekerjaan yang lain. Atau dengan kata lain diperlukan suatu manajemen pemerintahan yang baik agar pekerjaan tersebut dapat berjalan lebih lancar, cepat, tepat, efektif dan efisien, dapat mewujudkan dan melaksanakan tugastugas pemerintahan tersebut mutlak diperlukan adanya aparatur pemerintah yang mampu melaksanakan tugasnya secara efektif dan efisien. Dalam melakukan suatu pekerjaan, seorang aparat atau pegawai hendaknya memiliki kinerja yang tinggi, akan tetapi hal tersebut sulit untuk dicapai, banyak pegawai yang memiliki kinerja yang rendah walaupun telah lama bekerja. Suatu 
organisasi pemerintahan telah berupaya untuk mewujudkan kinerja pemerintahan menuju kinerja yang efektif dan efesien sehingga azas manfaat suatu program dan kegiatan dirasakan langsung oleh masyarakat.

Dengan adanya PP No 29 tahun 2014 tentang SAKIP, maka kinerja pemerintah baik pusat maupun daerah mempunyai tolak ukur yang sama, penilaian evaluasi terhadap kinerja pemerintah daerah dilakukan oleh Kementerian Pendayagunaan Aparatur Negara dan Reformasi Birokrasi setiap tahunnya, sedangkan penilaian evaluasi kinerja SKPD dilaksanakan oleh Inspektorat Kabupaten sebagai Aparat Pengawas Internal Pemerintah.

Penilaian evaluasi SAKIP SKPD dilaksanakan setiap tahun dan dilaksanakan penilaian SAKIP atas tahun sebelumnya, sehingga setiap SKPD akan mempunyai raport penilaian atas kinerjanya. Predikat penilaian ini akan dapat menggambarkan kinerja SKPD tahun sebelumnya. Adapun predikat penilaian kinerja SKPD yakni dari AA (sangat memuaskan), A (memuaskan), B (sangat baik ), B (Baik ),CC (Cukup), C (Kurang) dan D (sangat kurang). Dengan adanya hasil penilaian atas kinerja SKPD melalui penilaian atas evaluasi SAKIP SKPD maka seorang Kepala Daerah dapat menerapkan reward dan punishment terhadap SKPD yang berkinerja dan kurang berkinerja.

Dalam sebuah organisasi dalam hal ini adalah Satuan Kerja Perangkat Daerah (SKPD), mempunyai sebuah aturan baik tertulis ataupun tidak tertulis, kebiasaan, sistem kepercayaan hal ini disebut dengan Budaya organisasi. Untuk menjalankan sebuah program dan kegiatan maka sumber daya manusia juga menjadi hal yang paling menentukan. Sumber daya manusia setiap SKPD akan dipengaruhi oleh pengetahuan, keterampilan dan perilaku dari pegawainya. Pengetahuan, keterampilan dan perilaku ini jika berada pada diri seorang pegawai maka dinamakan Kompetensi Individu.

Setiap pegawai mempunyai Sasaran Kinerja Pegawai (SKP) yang dibuat setiap awal tahun, SKP merupakan indikator kinerja individu yang harus dilaporkan. Semua SKP harus merupakan hasil dari breakdown dari indikator kinerja atasannya, sehingga jika ditarik keatas maka Indikator Kinerja Sasaran dan Indikator Kinerja Utama merupakan cermin indikator Kinerja Organisasi. Selanjutnya target Kinerja yang telah tertuang di dalam dokumen Perencanaan dan dioperasionalkan dengan DPA dituangkan lagi dalam Rencana Aksi. Hasil dari proses perencanaan sampai dengan pelaksanaan harus dapat dipertanggungjawabkan oleh setiap SKPD baik dari sisi keuangan atau sisi pencapaian target Kinerja. Dokumentasi proses tersebut harus dapat dipertanggung-

jawabkan (Acountabel).

Pada tahun 2018 Inspektorat Kabupaten Tabalong telah melaksanakan penilaian evaluasi SAKIP SKPD atas kinerja tahun 2017, dari hasil penilaian atas penilaian kinerja SKPD tahun 2017 tersebut terdapat penilaian kinerja SKPD yang beragam. Adanya kesenjangan penilaian kinerja antar SKPD tersebut menjadi suatu permasalahan yang harus dapat dipecahkan bersama. Berikut data hasil evaluasi penilaian kinerja melalui evaluasi Sistem Akuntabilitas Kinerja Instansi Pemerintah (SAKIP) SKPD tahun 2018.Berikut data hasil penilaian SAKIP KPD pada tahun 2018 : Tabel 1.1

\begin{tabular}{|c|c|c|c|c|}
\hline \multicolumn{5}{|c|}{$\begin{array}{c}\text { Data Hasil Evaluasi SAKIP Pada } 9 \text { SKPD } \\
\text { Kabupaten Tabalong }\end{array}$} \\
\hline No & Nama SKPD & Skor / Nilai & Kategori & Keterangan \\
\hline 1 & Dinas Lingkungan Hidup & 72,96 & $B B$ & Sangat Baik \\
\hline 2 & Dinas Tenaga Kerja & 71,31 & BB & Sangat Baik \\
\hline 3 & Inspektorat & 70,19 & $B B$ & Sangat Baik \\
\hline 4 & Dinas P2AKB & 68,92 & B & Baik \\
\hline 5 & Dinas Kesehatan & 66,36 & $B$ & Baik \\
\hline 6 & Badan Kesbangpol & 65,34 & $B$ & Baik \\
\hline 7 & Dinas Ketahanan Pangan & 48,12 & C & Kurang \\
\hline 8 & Dinas Perikanan & 44,22 & C & Kurang \\
\hline 9 & Dinas Pertanian & 41,00 & C & Kurang \\
\hline
\end{tabular}

Sumber : Inspektorat Kabupaten Tabalong, 2018 
Berdasarkan latar belakang yang diuraikan diatas maka penulis tertarik untuk mengadakan penelitian lebih lanjut terkait dengan faktor dari budaya organisasi, kompetensi pegawai dan akuntabilitas kinerja, dan tema judul yang penulis kemukakan adalah Pengaruh Budaya Organisasi, Kompetensi Pegawai dan Akuntabilitas Kinerja Terhadap Kinerja SKPD Di Kabupaten Tabalong.

\section{Studi Literatur}

\section{a. Budaya Organisasi}

Budaya organisasi merupakan sistem makna bersama yang dianut oleh anggota anggota yang membedakan suatu organisasi dari organisasi lain, sistem ini merupakan seperangkat karakteristik utama yang dihargai oleh suatu organisasi. Budaya organisasi berkaitan dengan bagaimana seorang karyawan / pegawai mempersepsikan karakteristik dari suatu budaya organisasi, bukan dengan apakah para karyawan / pegawai menyukai budaya atau tidak (Robbins,2005:305).

Creemers dan Reynolds (dalam Soetopo, 2010, h.122) menyatakan bahwa "organizational culture is a pattern of beliefs and expectation shared by the organization's members" (budaya organisasi adalah pola keyakinan dan harapan bersama oleh anggota organisasi). Sedangkan Greenberg dan Baron (dalam Soetopo, 2010, h.122) menekankan budaya organisasi sebagai kerangka kognitif yang berisi sikap, nilai, norma perilaku, dan ekspektasi yang dimiliki oleh anggota organisasi.

Gibson, Ivanichevich, dan Donelly (dalam Soetopo, 2010, h.123) menyatakan bahwa budaya organisasi adalah kepribadian organisasi yang mempengaruhi cara bertindak individu dalam organisasi. Pengertian lain menurut Kast dan Rosenzweig (dalam Hakim, 2011, h.151) mendefinisikan budaya organisasi sebagai suatu sistem nilai dan kepercayaan yang dianut bersama yang berinteraksi dengan orang-orang suatu perusahaan, struktur organisasi dan sistem pengawasan untuk menghasilkan norma-norma perilaku.
Penelitian yang berkaitan degan Budaya Organisasi dilakukan oleh Ultafakoh Paramitha Dimulyo,Raden Andi Sularso dan Handriyono (2018) dengan judul penelitiannya Pengaruh Budaya Organisasi dan Disiplin Kerja terhadap Motivasi dan Kinerja Karyawan Perbankan,. Dengan metode penentuan responden menggunakan purposive pengambilan sampel dan total 115 karyawan perbankan. Analisis data dengan

menggunakan analisis jalur. Dalam penelitian ini menunjukan bahwa Budaya organisasi memiliki pengaruh yang signifikan terhadap motivasi kerja karyawan Bank Jatim Cabang Banyuwangi. Budaya organisasi yang dimiliki menjadi perilaku positif karyawan dalam bekerja yang akan meningkatkan motivasi kerja.

\section{b. Kompetensi Pegawai}

Kompetensi menurut Spencer dan Spencer dalam Palan (2007) adalah sebagai karakteristik dasar yang dimiliki oleh seorang individu yang berhubungan secara kausal dalam memenuhi kriteria yang diperlukan dalam menduduki suatu jabatan. Kompetensi terdiri dari 5 tipe karakteristik, yaitu :

1. Motif (kemauan konsisten sekaligus yang menjadi sebab dari tindakan).

2. Faktor Bawaan (karakter dan respom yang konsisten).

3. Konsep Diri (gambaran diri).

4. Pengetahuan (informasi dalam bidang tertentu).

5. Keterampilan (kemampuan untuk melaksanakan tugas).

Secara lebih rinci, Spencer dan Spencer dalam Palan (2007:84) mengemukakan bahwa kompetensi menunjukkan karakteristik yang mendasari perilaku yang menggambarkan motif, karakteristik pribadi (ciri khas), konsep diri, nilai-nilai, pengetahuan atau keahlian yang dibawa seseorang yang berkinerja unggul (superior performer) di tempat kerja.

Pada penelitian ini pegawai yang dimaksud adalah pegawai ASN yang bekerja di Satuan Kerja Perangkat Daerah (SKPD). Yang dimaksud pegawai ASN (UU ASN No.5 tahun 2014 pasal 1 ayat 2) adalah 
pegawai negeri sipil dan pegawai pemerintah dengan perjanjian kinerja yang diangkat oleh pejabat pembina kepegawaian dan diserahi tugas dalam suatu jabatan pemerintahan atau diserahi tugas negara lainnya dan digaji berdasarkan peraturan perundang-undangan.

Sedangkan kompetensi pegawai ASN menurut Undang-Undang ASN, pasal 69 ayat 3 terdiri dari tiga kompetensi yakni :

1) Kompetensi teknis, yang diukur dari tingkat spesialisasi pendidikan, pelatihan teknis fungsional dan pengalaman bekerja secara teknis;

2) Kompetensi manajerial, yang diukur dari tingkat pendidikan, pelatihan struktural atau manajemen dan pengalaman kepemimpinan;

3) Kompetensi sosial-kultural, yang diukur dari pengalaman kerja berkaitan dengan masyarakat majemuk dalam hal agama,suku dan budaya sehingga memiliki wawasan kebangsaan.

Penelitian yang dilakukan oleh Acep Dedi Supriadi,Suharto,Sodikin ( 2018) dengan judul penelitiannya Pengaruh kompetensi dan budaya organisasi terhadap kinerja karyawan dengan motivasi sebagai variabel mediasi pada Direktorat Jenderal Perimbangan Keuangan-Kementerian Keuangan, Indonesia, penelitian ini menganalisis pengaruh kompetensi dan budaya organisasi pada kinerja karyawan melalui motivasi sebagai mediasi variabel.. Teknik pengumpulan data dalam penelitian ini adalah studi literatur dan kuesioner.Hasil penelitian pertama ini menunjukkan bahwa kompetensi dan budaya organisasi secara simultan berpengaruh positif dan signifikan terhadap motivasi. Selanjutnya berdasarkan hasil uji parsial, kompetensi memiliki berpengaruh positif tetapi tidak signifikan terhadap motivasi, sedangkan pengaruh budaya organisasi terhadap motivasi adalah positif dan signifikan. Hasil kedua menunjukkan bahwa kompetensi, budaya organisasi, dan motivasi berpengaruh positif dan signifikan pada kinerja karyawan.

\section{c. Akuntabilitas Kinerja}

Akuntabilitas merupakan kewajiban dari individu-individu atau penguasa yang dipercayakan untuk mengelola sumber daya publik dan yang bersangkutan dengannya untuk dapat menjawab hal-hal yang menyangkut kebijakan fiskal, managerial dan program (Haris ,2007: 349).

Kinerja merupakan hasil kerja secara kualitas dan kuantitas yang dapat dicapai oleh seorang pegawai dalam melaksanakan tugas sesuai dengan tanggung jawab yang diberikan kepadanya. Kinerja adalah tingkat keberhasilan dalam melaksanakan tugas, serta kemampuan untuk mencapai tujuan yang telah ditetapkan. Kinerja dikatakan baik dan sukses jika tujuan yang diinginkan dapat tercapai dengan baik (Gibson et..al., 2007:171)

Akuntabilitas kinerja pada Pegawai Negeri Sipil menurut PP No 30 tahun 2019 tentang Penilaian Kinerja Pegawai Negeri Sipil bahwa kinerja merupakan hasil kerja yang dicapai oleh setiap PNS pada organisasi sesuai dengan Sasaran Kinerja Pegawai (SKP) dan Perilaku Kerja.

Yosueng Han dan Sounman Hong (2016), dalam penelitiannya yang berjudul The impact of Accountability on Organizational Performance in the U.S Federal Government. Penelitian ini menguji hubungan antara tingkat kinerja dan akuntabilitas organisasi dalam tiga fungsi sumber daya manusia manajemen (HRM) yakni stafing, evaluasi kinerja, dan kompensasi .Hasil penelitian menunjukan bahwa tingkat akuntabilitas dimanifestasikan dalam kepegawaian, evaluasi kinerja, dan kompensasi semua positif dan secara signifikan mempengaruhi kinerja organisasi. 


\section{Kerangka Konseptual dan Hipotesis}

\section{a. Kerangka Konseptual}

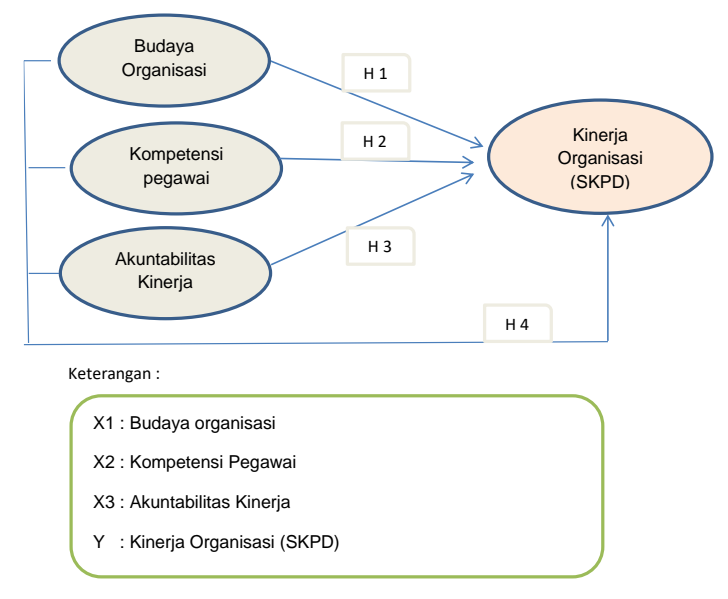

Gambar 3.1 Kerangka Konseptual

\section{b. Hipotesis}

Berdasarkan kerangka konseptual diatas maka hipotesis penelitian ini adalah sebagai berikut :

1) Budaya organisasi berpengaruh positif dan signifikan terhadap kinerja organisasi (SKPD) di Kabupaten Tabalong.

2) Kompetensi pegawai berpengaruh positif dan signifikan terhadap kinerja organisasi (SKPD) di Kabupaten Tabalong.

.3) Akuntabilitas kinerja berpengaruh positif dan signifikan terhadap kinerja organisasi (SKPD) di Kabupaten Tabalong

4) Budaya organisasi, kompetensi pegawai dan akuntabilitas kinerja diduga secara

bersama (simultan) berpengaruh positif

dan signifikan terhadap kinerja

organisasi

(SKPD) di Kabupaten Tabalong.

5) Kompetensi Pegawai berpengaruh dominan

terhadap kinerja organisasi (SKPD) di Kabupaten Tabalong.

\section{Metode Penelitian}

\section{a. Lokasi Penelitian}

Penelitian ini dilaksanakan pada 9 SKPD yakni Dinas Lingkungan Hidup, Dinas Tenaga Kerja, Inspektorat, Dinas Kesehatan , Badan Kesatuan Bangsa dan
Politik, Dinas Pemberdayaan Perempuan Perlindungan Anak dan KB, Dinas Ketahanan Pangan, Dinas Pertanian dan Dinas Perikanan di Kabupaten Tabalong, Provinsi Kalimantan Selatan.

\section{b. Populasi dan Sampel}

Populasi adalah wilayah generalisasi yang terdiri atas obyek/subyek yang mempunyai kualitas dan karakteristik tertentu yang ditetapkan oleh peneliti untuk dipelajari dan kemudian ditarik kesimpulannya (Sugiyono, 2012). Suharsimi Arikunto mengatakan bahwa populasi merupakan keseluruhan subyek penelitian.Populasi dalam penelitian ini adalah pada 9 SKPD lingkup Kabupaten Tabalong yang telah dilakukan penilaian evaluasi SAKIP tahun 2018 dengan kriteria hasil penilaian SAKIP yakni 3 SKPD dengan kriteria BB (Sangat Baik),3 SKPD dengan kriteria B (Baik) dan 3 SKPD dengan kriteria $C$ (Kurang) dengan jumlah pegawai yang menjadi populasi dalam penelitian ini adalah 405 orang .

Sampel adalah sejumlah individu yang diambil dari populasi yang mewakilinya. Sedangkan menurut Suharsimi Arikunto sampel adalah sebagian atau

wakil populasi yang diteliti. Teknik pengambilan sampel yang digunakan dalam penelitian ini adalah teknik Proportional Random Sampling. Proportional Random Sampling/pengambilan sampel acak stratifikasi proposional adalah metode yang di gunakan bila jumlah unit penelitian berbeda antara strata yang satu dengan strata yang lain atau untuk memilih sampel dari banyaknya subyek penelitian yang tidak sama.

Oleh karena itu, untuk memperoleh sampel yang representatif, pengambilan subjek dari setiap strata atau setiap wilayah ditentukan seimbang atau sebanding dengan banyak subjek dalam masing-masing strata atau wilayah.Dalam pengambilan sampel peneliti berpedoman pada Suharsimi Arikunto yang menyatakan bahwa apabila subyeknya kurang dari 100, lebih baik 
diambil semua,sehingga penelitiannya merupakan penelitian populasi. Selanjutnya jika subyeknya besar (lebih dari 100 orang) dapat menggunakan sampel. Menurutnya sampel diambil antara $10 \%$ - $15 \%$ hingga 20 $\%-25 \%$ atau bahkan boleh lebih dari $25 \%$ dari jumlah populasi yang ada.

Berdasarkan tata cara pengambilan sampel di atas, maka sampel yang akan diambil dalam penelitian ini adalah sebanyak 405 pegawai yang tersebar pada 9 SKPD di Kabupaten Tabalong yang telah dilakukan evaluasi kinerjanya melalui evaluasi implementasi SAKIP. Adapun SKPD tersebut yakni Dinas Lingkungan Hidup, Dinas Tenaga Kerja, Inspektorat, Dinas Kesehatan, Badan Kesatuan Bangsa dan Politik, Dinas Pemberdayaan Perempuan Anak dan KB, Dinas Ketahanan Pangan, Dinas Perikanan dan Dinas Pertanian.

Dengan menggunakan teknik pengambilan sampel proportional random sampling yaitu $20 \%$ x $405=80$, dengan demikian jumlah sampel yang menjadi subyek penelitian dengan menggunakan proportional random sampling yaitu 80 pegawai dari populasi pada 9 SKPD di Kabupaten Tabalong yang telah dilakukan penilaian evaluasi kinerjanya pada tahun 2018, dengan perincian sebagai berikut :

Tabel 4.2 Jumlah Sampel berdasarkan Propotional Random Sampling

\begin{tabular}{|c|c|c|c|}
\hline No & SKPD & $\begin{array}{c}\text { Hasil } \\
\text { Evaluasi } \\
\text { SAKIP }\end{array}$ & Sampel \\
\hline 1. & Dinas Lingkungan Hidup & Sangat Baik & 12 \\
\hline 2. & Dinas Tenaga Kerja & Sangat Baik & 8 \\
\hline 3. & Inspektorat & Sangat Baik & 7 \\
\hline 4. & Dinas Kesehatan & Baik & 15 \\
\hline 5. & Badan Kesbangpol & Baik & 4 \\
\hline 6. & Dinas P2AKB & Baik & 11 \\
\hline 7. & $\begin{array}{l}\text { Dinas Ketahanan } \\
\text { Pangan }\end{array}$ & Kurang & 5 \\
\hline 8. & Dinas Perikanan & Kurang & 5 \\
\hline 9. & Dinas Pertanian & Kurang & 13 \\
\hline \multicolumn{3}{|c|}{ Jumlah } & 80 \\
\hline
\end{tabular}

Sumber Lakip Kabupaten Tabalong 2018

\section{c. Pengukuran Variabel Penelitian}

Data yang hendak diperoleh dalam penelitian ini menggunakan metode survei dengan cara menggunakan instrumen kuesioner. Menurut Sugiyono (2011) Kuesioner adalah teknik pegumpulan data yang dilakukan dengan cara memberi seperangkat pertanyaan atau pertanyaan tertulis kepada responden untuk dapat dijawabnya, hal ini diperkuat oleh Oie I (2010) yang menyatakan bahwa kuesioner merupakan daftar pertanyaan yang digunakan oleh seorang peneliti untuk memperoleh data secara langsung dari sumber proses komunikasi atau dengan mengajukan pertanyaan.

Kuesioner ini dimaksudkan untuk memperoleh jawaban dari responden tentang budaya organisasi, kompetensi pegawai,akuntabilitas kinerja dan kinerja organisasi (SKPD) pada 9 SKPD di kabupaten Tabalong, responden yang telah ditentukan hanya perlu menjawab pertanyaan dalam kuesioner.

Pengukuran nilai variabel pada itemitem pertanyaan pada kuesioner penelitian dengan menggunakan skala, yakni skala likert. Skala ini dirancang untuk menilai sejauhmana subjek setuju atau tidak setuju dengan pertanyaan yang diajukan. Menurut Ridwan (2002) skala likert digunakan untuk mengukur sikap dan persepsi seseorang atau kelompok tentang kejadian atau gejala sosial. Skala likert digunakan untuk mengukur respon objek ke dalam 5 poin (bernilai 1 s.d 5), sehingga tipe data yang digunakan adalah tipe data interval. Untuk memudahkan dalam menganalisis data maka digunakan teknik memanipulasi data ordinal menjadi data interval dengan bantuan skala likert yaitu memberikan penilaian yang berjenjang, seperti yang berikut ini :

a) Angka 1 = Sangat Tidak Penting / Sangat Tidak Setuju / Tidak Pernah

b) Angka 2 = Tidak Penting / Tidak Setuju / Hampir Tidak Pernah

c) Angka 3 = Penting / Netral / Kadang - Kadang

d) Angka 4 = Sangat Penting / Setuju / Sering 
e) Angka 5 = Sangat Penting Sekali / Sangat Setuju / Sangat Sering

\section{d. Analisis Data}

Teknik analisis data
merupakan suatu proses
mengorganisir dan menurutkan data
kedalam pola, kategori dan satuan
sehingga dapat dirumuskan hipotesis
kerja yang didasarkan oleh data,
langkah-langkah yang dilakukan
dalam proses analisis ini yaitu:

\section{1) Analisis Deskriptif}

Metode analisis deskriptif digunakan untuk melihat gambaran dari variabel-variabel penelitian yaitu budaya organisasi, kompetensi pegawai,akuntabilitas kinerja dan kinerja organisasi (SKPD) pada 9 SKPD di kabupaten Tabalong, peneliti akan menggunakan alat analisis deskriptif dengan rentang skala.

\section{2) Analisa Kuantitatif}

a) Uji Validitas

Uji validitas berguna untuk mengetahui apakah pertanyaan pada kuesioner yang harus dibuang atau diganti karena dianggap tidak relevan. Pengujian dilakukan secara statistik, dapat dilakukan secara manual atau dengan menggunakan komputer (Umar,2008). Adapun langkah-langkah dalam mengukur validitas kuesioner adalah sebagai berikut :

1. Melakukan uji coba kuesioner dengan meminta 30 responden untuk menjawab pertanyaan-pertanyaan yang ada. Dengan jumlah minimal 30 orang ini maka distribusi skor akan lebih mendekati kurva normal (Umar, 2008).

2. Hasil jawaban responden kemudian dimasukan ke dalam tabel tabulasi.

3. Melakukan uji validitas dari kuesioner dengan menggunakan sofware SPSS.

Menurut Priyatno,2012 tentang validitas suatu data, yakni :

1. Jika perbandingan antara nilai " $\mathrm{r}$ hitung " lebih besar dari dengan " $r$ tabel " ( $r$ hitung $>r$ tabel), maka item pertanyaan tersebut adalah valid, jika $r$ hitung $<\mathrm{r}$ tabel, maka item pertanyaan tidak valid.

2. Jika signifikansi $<0,05$ maka item dikatakan valid, tetapi jika signifikansi > 0,05 maka item tidak valid.

b) Uji Reliabilitas

Reliabilitas/ keandalan (derajat konsistensi/keajegan)adalah ukuran yang menunjukan seberapa tinggi suatu instrumen dapat dipercaya atau dapat diandalkan, artinya reabilitas menyangkut ketepatan ( konsisten) alat ukur (Mustafa, 2009).

Untuk uji reliabilitas kuesioner dalam penelitian ini, peneliti menggunakan program SPSS dalam hal untuk menguji reliabilitas dari butir-butir pertanyaan dalam kuesioner penelitian.

c) Uji Asumsi Klasik

Dalam sebuah penelitian untuk meyakinkan bahwa persamaan garis regresi yang diperoleh adalah linier dan dapat dipergunakan (valid) untuk mencari peramalan, maka dilakukan- lah dilakukanlah uji normalitas, dan multikolinearitas.

\section{Uji Normalitas}

Uji normalitas dilakukan untuk melihat apakah dalam model regresi variabel terikat dan variabel bebas keduanya mempunyai distribusi normal atau tidak. Model regresi yang baik adalah model regresi yang berdistribusi normal (Wijaya,2012).

Pada prinsipnya normalitas dapat dideteksi dengan melihat penyebaran data (titik) pada sumbu diagonal dari grafik atau dengan melihat histogram dari residualnya (Ghozali,2005). Dasar pengambilan keputusannya adalah sebagai berikut:

- Jika data (titik) menyebar disekitar garis diagonal dan mengikuti arah garis diagonal atau grafik histogramnya akan menunjukan pola distribusi normal, maka model regresi memenuhi asumsi normalitas.

- Jika data menyebar jauh dari diagonal atau tidak mengikuti arah garis 
diagonalnya atau grafik histogram tidak menunjukan pola distribusi normal, maka model regresi tidak memenuhi asumsi normalitas.

\section{Uji Multikolinearitas}

Uji Multikolinearitas bertujuan untuk menguji apakah model regresi ditemukan adanya korelasi antar variable bebas. Model regresi yang baik seharusnya tidak terjadi korelasi diantara variable independen (Ghozali, 2009). Suatu analisis dikatakan tidak terjadi gejala multikolinearitas jika nilai VIF (Variance Inflation Factor) < 10 (Ghozali, 2009).

Secara umum untuk mendeteksi adanya multikolinearitas adalah dengan melihat adanya nilai $\mathrm{R}^{2}$ yang tinggi dalam model tetapi tingkat signifikannya yang sangat kecil dari hasil regresi terebut dan cenderung banyak yang tidak signifikan.

\section{Uji Heterokedastisitas}

Heterokedastisitas menunjukan bahwa variasi variabel tidak sama untuk semua pengamatan. Jika varian dari residual satu pengamatan ke pengamatan lain tetap maka disebut homokedastisitas. Model regresi yang baik adalah yang homokedastisitas atau tidak terjadi heterokedastisitas karena data cross section memiliki data yang mewakili berbagai ukuran ( kecil, sedang dan besar) (Wijaya, 2012).

Menurut Wijaya (2012), salah satu cara untuk melihat adanya problem heterokedastisitas adalah dengan melihat grafik plot antara nilai prediksi variabel terikat (ZPRED) dengan residual (SRESID). Cara menganalisisnya sebagai berikut :

- Dengan melihat apakah titik - titik memiliki pola tertentu yang teratur seperti bergelombang, melebar kemudian menyempit. Jika terjadi, maka dapat diindikasikan terjadinya heterokedastisitas.

- Jika terdapat pola tertentu yang jelas, serta titik - titik menyebar keatas dan kebawah angka 10 pada sumbu Y, maka indikasinya tidak terjadi heterokedastisitas.

\section{3) Analisis Regresi Linier Berganda}

Analisis regresi linier berganda digunakan untuk mengetahui seberapa besar pengaruh variabel bebas (independen), yakni budaya organisasi $\left(\mathrm{X}_{1}\right)$, kompetensi pegawai $\left(X_{2}\right)$ dan akuntabilitas kinerja $\left(X_{3}\right)$ terhadap variabel terikatnya (dependen) yaitu kinerja organisasi / SKPD (Y). Menurut Ghozali (2005) rumus persamaan linier berganda adalah sebagai berikut :

$$
\mathbf{Y}=\mathbf{a}+\boldsymbol{\beta}_{1} \mathbf{X}_{1}+\boldsymbol{\beta}_{2} \mathbf{X}_{2}+\boldsymbol{\beta}_{3} \mathbf{X}_{3}
$$

Dimana :

$$
\begin{aligned}
& \mathbf{Y}=\text { Kinerja organisasi } / \mathrm{SKPD} \\
& \mathbf{a}=\text { Konstanta } \\
& \boldsymbol{\beta}_{\mathbf{1}}=\text { Koefisien regresi } \\
& \mathbf{X}_{\mathbf{1}}=\text { Budaya organisasi } \\
& \mathbf{X}_{\mathbf{2}}=\text { Kompetensi pegawai } \\
& \mathbf{X}_{\mathbf{3}}=\text { Akuntabilitas kinerja }
\end{aligned}
$$

\section{4) Analisis Korelasi Berganda (Simultan)}

Dalam analisis kolerasi yang dicari adalah koefisien kolerasi yaitu angka yang menyatakan derajat hubungan antara variabel independen (X) dengan variabel dependen (Y) atau untuk mengetahui kuat atau lemahnya hubungan antara variabel independen dengan variabel dependen.

Analisis korelasi berganda simultan) dugunakan untuk mengetahui derajat atau kekuatan hubungan antara seluruh variabel $\mathrm{X}$ terhadap variabel $\mathrm{Y}$ secara bersamaan. Menurut Sugiyono (2014:256) koefisien korelasi pada keadaan dimana terdapat lebih dari 2 variabel bebas, koefisien korelasi juga dapat dicari nilainya dengan rumus persamaan sebagai berikut : 


$$
\begin{aligned}
& R_{x 1, x 2, \ldots, x i, y}=\sqrt{\frac{b_{1}, \sum x_{1} y+b_{2} \cdot \sum x_{2} y+\cdots+b_{7} \cdot \sum x_{i} y}{\sum y^{2}}} \\
& \sum y^{2}=\sum Y^{2}-\frac{\left(\sum Y\right)^{2}}{n} \\
& \sum x_{i} y=\sum X_{i} Y-\frac{\left(\sum X_{i}\right)\left(\sum Y\right)}{n}
\end{aligned}
$$

Dimana :

$\mathrm{n}=$ Jumlah data dari setiap variabel

$\sum \mathrm{X}_{\mathbf{i}}=$ Jumlah Data $\mathrm{X}_{\mathbf{i}}$

$\sum \mathrm{Y}=$ Jumlah dari $\mathrm{Y}$

$\sum \mathrm{Y}^{2}=$ Jumlah dari $\mathrm{Y}^{2}$

$\sum X_{\mathbf{i}} \mathrm{Y}=$ Jumlah Data $\mathrm{X}_{\mathbf{i}} \mathrm{Y}$

$b_{1} \ldots b_{1}=$ Koefesien regresi masingmasing variabel

Koefisien korelasi disimbolkan dengan huruf R. Besarnya Koefisien korelasi adalah antara -1 ; 0 ; dan +1 . Besarnya korelasi -1 adalah negatif sempurna yakni terdapat hubungan di antara dua variabel atau lebih namun arahnya terbalik, +1 adalah korelasi yang positif sempurna (sangat kuat) yakni adanya sebuah hubungan di antara dua variabel atau lebih tersebut, sedangkan koefisien korelasi 0 dianggap tidak terdapat hubungan antara dua variabel atau lebih yang diuji sehingga dapat dikatakan tidak ada hubungan sama sekali.

Menurut Sugiyono (2007) pedoman untuk interprestasi koefisien korelasi adalah sebagai berikut :

$$
\begin{aligned}
& >0,00-0,199=\text { sangat rendah } \\
& >0,20-0,399=\text { rendah } \\
& >0,40-0,599=\text { sedang } \\
& >0,60-0,799=\text { kuat } \\
& >0,80-1,00=\text { sangat kuat }
\end{aligned}
$$

\section{Hasil Penelitian dan Pembahasan 5.3.1 Uji Instrumen}

Data merupakan penggambaran variabel yang diteliti dan berfungsi sebagai alat pembuktian hipotesis. Oleh karena itu, benar dan tidaknya data sangat menentukan berkualitas tidaknya hasil penelitian.
Kemudian benar dan tidaknya data tergantung dari baik tidaknya instrumen yang digunakan dalam pengumpulan data. Instrumen yang baik harus memenuhi dua persyaratan penting yaitu valid dan reliabel. Pengujian instrumen kuesioner dengan meminta 30 responden untuk menjawab pertanyaan-pertanyaan yang ada. Dengan jumlah minimal 30 orang maka distribusi skor (nilai) akan lebih mendekati kurva normal (Umar, 2008).

\section{1) Uji Validitas}

Uji validitas ini dilakukan untuk melihat sejauhmana indikator-indikator yang digunakan dalam kuesioner membentuk konsep dan dapat mewakili variabel yang dibentuk dalam penelitian ini. Suatu data dapat dikatakan valid jika pertanyaanpertanyaan pada suatu kuesioner tersebut mampu mengungkapkan sesuatu yang diukur oleh kuesioner tersebut. Item-item pertanyaan yang ada dalam kuesioner diuji terhadap konstruk, apakah valid atau tidak valid. Kalau ternyata tidak valid maka item pertanyaan yang tidak valid tersebut akan dikeluarkan dari kuesioner atau pertanyaan dalam kuesioner tersebut diperbaiki.

Menurut Priyatno (2012) suatu data dapat dikatakan valid jika memenuhi kriteria sebagai berikut :

a. Jika perbandingan antara nilai " $\mathrm{r}$ hitung " lebih besar dari dengan " $\mathrm{r}$ tabel " $(\mathrm{r}$ hitung > $\mathrm{r}$ tabel), maka item pertanyaan tersebut adalah valid, jika $r$ hitung $<\mathrm{r}$ tabel, maka item pertanyaan tidak valid.

b. Jika signifikansi $<0,05$ maka item dikatakan valid, tetapi jika signifikansi $>0,05$ maka item tidak valid.

Berdasarkan hal tersebut diatas maka dapat disimpulkan bahwa validnya suatu item-item pertanyaan pada instrumen kuesioner akan dipengaruhi oleh nilai $\mathrm{r}$ hitung, jika nilai $\mathrm{r}$ hitung $>$ nilai $\mathrm{r}$ tabel dan jika nilai signifikasi < 0,05. Dalam penelitian ini jumlah sampel untuk pengujian validitas kuesioner ini adalah 30 orang $(n=30)$, maka sesuai dengan rumus untuk mencari $r$ tabel yakni $(\mathrm{df}=\mathrm{n}-2)$ sehingga $\mathrm{df}=28$. Dari $\mathrm{r}$ tabel dengan Sig 5\% maka didapat nilai $r$ tabel yakni 0,361 . 
Pengujian validitas item-item pertanyaan untuk kuesioner pada variabel Budaya Organisasi semua pertanyaan memiliki nilai $r$ hitung $>$ nilai $\mathrm{r}$ tabel product moment 0,361 dan sig. (2tailed) $<0,05$ dengan tingkat signifikasi 0,05 . Sehingga seluruh item pertanyaan untuk variabel Budaya Organisasi dalam penelitian ini dinyatakan semuanya valid (data terlampir), sebagaimana disajikan pada tabel 5.10 dibawah ini :

Tabel 5.10

\begin{tabular}{|c|c|c|c|c|c|c|}
\hline \multicolumn{7}{|c|}{ Rekapitulasi Hasil Uji Validitas Budava Organisasi } \\
\hline Variabel & $\begin{array}{l}\text { Item } \\
\text { Pertanyaan }\end{array}$ & $\begin{array}{l}\text { Pearson } \\
\text { Corelati } \\
\text { on (r } \\
\text { hitung) }\end{array}$ & $\begin{array}{l} \\
\mathrm{r} \text { tabel } \\
(\mathrm{N}-2)\end{array}$ & $\begin{array}{l}\mathrm{Sig} \\
(2- \\
\text { tailed })\end{array}$ & $\begin{array}{l}\text { Tingkat } \\
\text { Signifikansi }\end{array}$ & Ket \\
\hline \multirow{3}{*}{$\begin{array}{l}\text { Budaya } \\
\text { Organisasi }\end{array}$} & X1.1 & 0,912 & 0,361 & 0,000 & 0,05 & Valid \\
\hline & $X 1.2$ & 0,839 & 0,361 & 0,000 & 0,05 & Valid \\
\hline & $X 1.3$ & 0,803 & 0,361 & 0,000 & 0,05 & Valid \\
\hline
\end{tabular}

Sumber : Data Primer Diolah, 2020

Kemudian pengujian validitas item-item pertanyaan untuk kuesioner pada variabel Kompetensi Pegawai, semua pertanyaan memiliki nilai $\mathrm{r}$ hitung > nilai $\mathrm{r}$ tabel product moment $(0,361)$ dan sig. (2-tailed) $<0,05$ dengan tingkat signifikasi 0,05 . Sehingga seluruh item pertanyaan untuk variabel Kompetensi Pegawai dalam penelitian ini dinyatakan semuanya valid (data terlampir), sebagaimana disajikan pada tabel 5.11 dibawah ini :

Tabel5.11

\begin{tabular}{|c|c|c|c|c|c|c|}
\hline \multicolumn{7}{|c|}{ Rekapitulasi Hasil Lji IValiditas Kompetensi Pẹgawai } \\
\hline Variabel & $\begin{array}{l}\text { Item } \\
\text { Pertanyad } \\
11\end{array}$ & $\begin{array}{l}\text { Pearson } \\
\text { Corelatio } \\
\text { n } \\
\text { hitung) }\end{array}$ & $\begin{array}{l}\text { I tabel } \\
(\mathrm{N}-2)\end{array}$ & $\begin{array}{l}\text { Sig } \\
\text { (2-tailed) }\end{array}$ & $\begin{array}{l}\text { Tingkat } \\
\text { Signifikan } \\
\text { si }\end{array}$ & Ket \\
\hline \multirow{4}{*}{$\begin{array}{l}\text { Kompeten } \\
\text { si Pegawai }\end{array}$} & X.1.1 & 0,552 & 0,361 & 0,000 & 0,05 & Valid \\
\hline & X2.2 & 0,835 & 0,361 & 0,000 & 0,05 & Valid \\
\hline & $X 2,3$ & 0,846 & 0,361 & 0,000 & 0,05 & Valid \\
\hline & X2.4 & 0,875 & 0,361 & 0,000 & 0,05 & Valid \\
\hline
\end{tabular}

Sumber: Data Primer Diolah, 2020
Sedangkan pada pengujian validitas item-item pertanyaan untuk kuesioner pada variabel Akuntabilitas Kinerja, semua pertanyaan memiliki nilai $\mathrm{r}$ hitung $>$ nilai $\mathrm{r}$ tabel product moment $(0,361)$ dan sig. (2tailed) $<0,05$ dengan tingkat signifikasi 0,05 . Sehingga seluruh item pertanyaan untuk variabel Akuntabilitas Kinerja dalam penelitian ini dinyatakan semuanya valid (data terlampir), sebagaimana disajikan pada tabel 5.12 dibawah ini :

Tabel 5.12

\begin{tabular}{|c|c|c|c|c|c|c|}
\hline & & WI & & & & \\
\hline Variabel & $\begin{array}{l}\text { Item } \\
\text { Pertanyaa } \\
n\end{array}$ & $\begin{array}{l}\text { Pearson } \\
\text { Corelatio } \\
n \\
\text { hitung) }\end{array}$ & 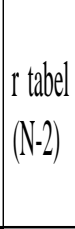 & $\begin{array}{l}\text { Sig } \\
(2 \text {-tailed) }\end{array}$ & $\begin{array}{l}\text { Tingkat } \\
\text { Signifíkan } \\
\text { si }\end{array}$ & Ket \\
\hline \multirow{3}{*}{$\begin{array}{l}\text { Akuntabilita } \\
\text { s Kinerija }\end{array}$} & X3.1 & 0,909 & 0,361 & 0,000 & 0,05 & Valid \\
\hline & X3.2 & 0,880 & 0,361 & 0,000 & 0,05 & Valid \\
\hline & $X 3,3$ & 0,704 & 0,361 & 0,000 & 0,05 & Valid \\
\hline
\end{tabular}

Sumber: Data Primer Diolah, 2020

Adapun untuk pengujian validitas item-item pertanyaan untuk kuesioner pada variabel Kinerja SKPD, semua pertanyaan memiliki nilai $r$ hitung $>$ nilai $\mathrm{r}$ tabel product moment $(0,361)$ dan sig. (2-tailed) $<0,05$ dengan tingkat signifikasi 0,05 . Sehingga seluruh item pertanyaan untuk variabel Kinerja SKPD dalam penelitian ini dinyatakan semuanya valid (data terlampir), sebagaimana disajikan pada tabel 5.13 dibawah ini :

Tabel 5.13

Rekapitulasi Hasil Uji Validitas Kinerja SKPD

\begin{tabular}{|c|c|c|c|c|c|c|}
\hline Variabel & $\begin{array}{l}\text { Item } \\
\text { Pertanyaa } \\
n\end{array}$ & \begin{tabular}{|l|} 
Pearson \\
Corelatio \\
n $\quad(\mathrm{r}$ \\
hitung)
\end{tabular} & $\begin{array}{l}\mathrm{r} \text { tabel } \\
(\mathrm{N}-2)\end{array}$ & $\begin{array}{l}\text { Sig } \\
\text { (2-tailed) }\end{array}$ & $\begin{array}{l}\text { Tingkat } \\
\text { Signifikan } \\
\text { si }\end{array}$ & Ket \\
\hline \multirow{4}{*}{$\begin{array}{l}\text { Kinerja } \\
\text { SKPD }\end{array}$} & Y 1.1 & 0,799 & 0,361 & 0,000 & 0,05 & Valid \\
\hline & Y 1.2 & 0,879 & 0,361 & 0,000 & 0,05 & Valid \\
\hline & Y1.3 & 0,845 & 0,361 & 0,000 & 0,05 & Valid \\
\hline & Y 1.4 & 0,742 & 0,361 & 0,000 & 0,05 & Valid \\
\hline
\end{tabular}

\section{2) Uji Reliabilitas}

Pengujian reliabilitas berkaitan dengan masalah adanya kepercayaan terhadap instrumen kuesioner. Suatu instrumen kuesioner 
dapat memiliki tingkat kepercayaan yang tinggi (konsisten) jika hasil pengujian instrumen tersebut menunjukan hasil yang tetap. Dengan demikian, masalah reliabilitas instrumen kuesioner berhubungan dengan ketepatan hasil. Uji reliabilitas digunakan untuk mengetahui tingkat kestabilan suatu alat ukur. Hasil pengukuran dapat dipercaya terhadap kelompok subjek yang sama dan akan diperoleh hasil yang relatif sama, selama aspek yang diukur dalam diri subjek tidak berubah (Wijaya $\mathrm{T}, 2012$ ).

Untuk menguji kehandalan kuesioner yang digunakan, maka dalam penelitian ini menggunakan uji reliabilitas. Tolak ukur reliabilitas adalah nilai cronbach's alpha yang diperoleh melalui perhitungan statistik. Menurut Malhotra dalam Harsani (2010), nilai alpha minimum yang diperoleh sebagai syarat kehandalan kuesioner adalah sebesar 0,60 . Hal ini berarti bahwa apabila nilai cronbach's alpha $<0,60$ maka kuesioner belum memenuhi syarat kehandalan.

Pada pengujian reliabilitas pertanyaan untuk kuesioner pada penelitian ini, instrumen kuesioner untuk variabel budaya organisasi, variabel kompetensi pegawai, variabel akuntabilitas kinerja dan variabel kinerja SKPD dinyatakan reliabel / handal. Untuk jelasnya dapat dilihat pada tabel 5.14 yang tersajikan sebagai berikut :

\begin{tabular}{|c|c|c|c|c|}
\hline \multicolumn{5}{|c|}{$\begin{array}{c}\text { Tabel 5.14 } \\
\text { Rekapitulasi Hasil Uji Reliabilitas }\end{array}$} \\
\hline No & Variabel & \begin{tabular}{|l|} 
Jumlah \\
Item \\
Pertanyaa \\
$\mathrm{n}$
\end{tabular} & $\begin{array}{l}\text { Cronbach's } \\
\text { Alpha } \\
\text { (r hitung) }\end{array}$ & Keterangan \\
\hline 1 & Budaya Organisasi (X1) & 3 & 0,810 & Reliabel \\
\hline 2 & $\begin{array}{l}\text { Kompetensi Pegawai } \\
\text { (X2) }\end{array}$ & 4 & 0,872 & Reliabel \\
\hline 3 & $\begin{array}{l}\text { Akuntabilitas } \text { Kinerja } \\
\text { (X3) }\end{array}$ & 3 & 0,784 & Reliabel \\
\hline 4 & Kinerja SKPD (Y) & 4 & 0,843 & Reliabel \\
\hline
\end{tabular}

Berdasarkan tabel 5.14 hasil pengujian reliabilitas kuesioner pada empat variabel penelitian memperlihatkan nilai cronbach's alpha masing-masing sebesar 0,810 untuk variabel budaya organisasi, untuk variabel kompetensi pegawai nilai cronbach's alpha adalah 0,872 dan nilai cronbach's alpha untuk variabel akuntabilitas kinerja sebesar 0,784 kemudian nilai cronbach's alpha sebesar 0,843 untuk variabel kinerja SKPD.

Dari nilai cronbach's alpha masingmasing variabel penelitian terlihat lebih besar dari nilai 0,60, dengan demikian dapat disimpulkan bahwa kuesioner yang digunakan untuk pengumpulan data untuk penelitian ini telah memenuhi syarat kehandalan dan reliabilitas. Sehingga kuesioner yang digunakan untuk mengumpulkan data yang berhubungan dengan variabel-variabel yang diteliti dinilai telah menunjukan ketepatan, keakuratan dan konsistensinya akan dapat mengungkapkan gejala yang berhubungan dengan variabel terkait.

\subsubsection{Uji Asumsi Klasik}

\section{Hasil Uji Normalitas}

Uji normalitas bertujuan untuk menguji apakah dalam model regresi, variabel bebas dan variabel terikat, keduanya terdis-

busikan secara normal ataukah tidak. Normalitas data dalam penelitian dapat dilihat dengan cara memperhatikan titiktitik pada Normal P-Plot of Regression Standardized Residual dari variabel terikat. Persyaratan dari uji normalitas adalah jika data yang menyebar di sekitar garis diagonal dan mengikuti arah garis diagonal, maka model regresi tidak memenuhi asumsi normalitas.

Berdasarkan grafik dibawah ini dapat dilihat bahwa data menyebar di sekitar garis diagonal dan mengikuti arah garis diagonal. Hal ini berarti bahwa nilai residual hasil regresi memenuhi asumsi normalitas. Berikut grafik hasil pengujian normalitas tersebut seperti pada gambar 5.1 dibawah ini : 


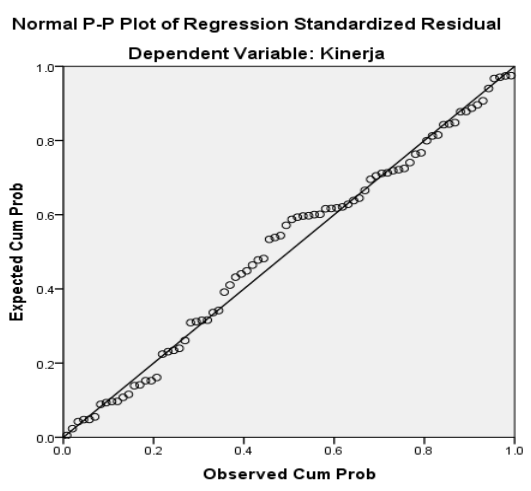

Sumber lampiran Output SPSS

Gambar 5.1 Hasil Pengujian Normalitas

\section{Hasil Uji Multikolinearitas}

Pengujian multikolinearitas bertujuan untuk mengetahui hubungan yang sempurna antar variabel bebas dalam model regresi.Gejala multikolinearitas dapat dilihat dari nilai tolerance dan nilai Varian Inflation Factor (VIF). Bila nilai VIF lebih kecil dari 10 dan nilai toleransinya di atas 0,1 atau $10 \%$ maka dapat disimpulkan bahwa model regresi tidak terjadi multikolinearitas (Ghozali,2005).

Berdasarkan tabel 5.15 seperti yang tertera dibawah ini nilai VIF dan Tolerance pada collinearity statistics menunjukkan tidak ada gejala multikolinearitas sebab VIF $<10$ dan tolerance $>0,1$. Hal ini menunjukan semua variabel bebas dalam penelitian ini lebih kecil dari 10 sedangkan nilai toleransi semua variabel bebas lebih besar dari $10 \%$ yang berarti tidak terjadi korelasi antar variabel yang nilainya lebih dari $90 \%$, dengan demikian dapat disimpulkan tidak terdapat gejala multikolinearitas dalam model regresi.

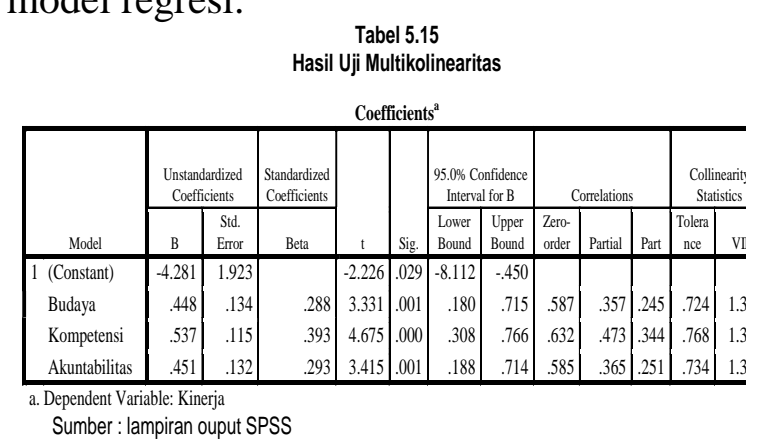

\section{Hasil Uji Heterokedastisitas}

Pengujian ini bertujuan untuk menguji apakah dalam sebuah model regresi terjadi ketidaksamaan varians dari residual, dari satu pengamatan ke pengamatan yang lain. Jika varians dari residual dalam satu pengamatan ke pengamatan yang lain tetap, maka disebut homokedastisitas, dan jika varians berbeda, disebut heterokedastisitas. Model regresi yang baik adalah tidak terjadi heterokedastisitas. Untuk mendeteksi ada tidaknya heterokedastisitas dapat digunakan metode grafik Scatterplot yang dihasilkan dari ouput program SPSS. Apabila pada gambar menunjukan bahwa titik-titik menyebar secara acak serta tersebar baik diatas maupun dibawah angka 0 pada sumbu Y, maka dapat disimpulkan tidak terjadi adanya heterokedastisitas pada model regresi (Ghozali,2005).

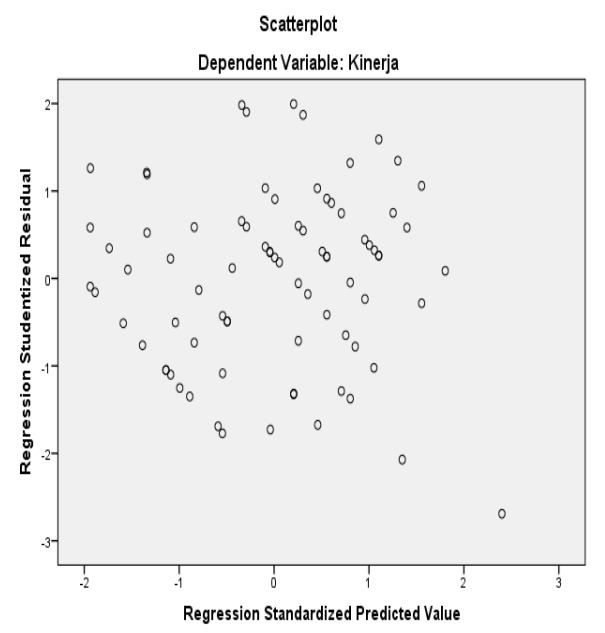

Sumber lampiran Output SPSS

Gambar 5.2 Hasil Pengujian Heterokedastisitas

Dari gambar diatas terlihat bahwa titik-titik yang acak, baik diatas maupun dibawah angka 0 dari sumbu $\mathrm{Y}$, sehingga dapat disimpulkan bahwa tidak terjadi penyimpangan asumsi klasik heterokedastisitas pada model regresi yang dibuat.

\subsubsection{Analisis Regresi}

Model persamaan regresi yang baik adalah yang memenuhi persyaratan uji asumsi klasik, yakni semua data berdistribusi normal, model harus bebas dari gejala 
multikolinearitas dan terbebas dari gejala heterokedatisitas. Dari analisis sebelumnya telah terbukti bahwa model persamaan yang diajukan dalam penelitian ini telah memenuhi persyaratan asumsi klasik sehingga model persamaan dalam penelitian ini dianggap baik. Analisis regresi digunakan untuk menguji hipotesis tentang pengaruh secara parsial variabel bebas terhadap variabel terikat, dalam hal ini untuk mengetahui seberapa besar pengaruh variabel bebas (independen), yakni budaya organisasi $\left(\mathrm{X}_{1}\right)$, kompetensi pegawai $\left(\mathrm{X}_{2}\right)$ dan akuntabilitas kinerja ( $\left.\mathrm{X}_{3}\right)$ terhadap variabel terikatnya (dependen) yaitu kinerja organisasi / SKPD (Y). Berdasarkan regresi linier berganda dengan program SPSS seperti pada tabel 5.16

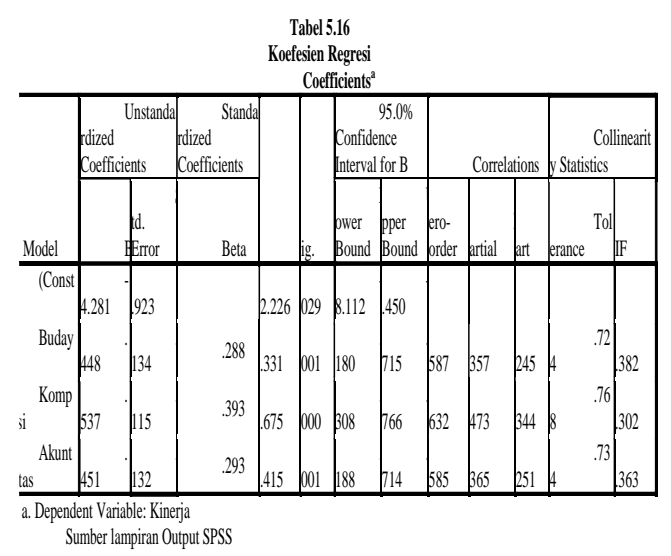

Berdasarkan tabel 5.16 dapat diketahui bahwa nilai konstan yaitu $\alpha=-4,281$ sedangkan koefisien variabel budaya organisasi adalah 0,448 koefisien variabel kompetensi pegawai adalah 0,537 koefisien variabel akuntabilitas kinerja adalah 0,451 . Berdasarkan tabel 5.16 dapat dibuat persamaan regresi sebagai berikut :

$$
\begin{aligned}
& Y=a+\beta_{1} X_{1}+\beta_{2} X_{2}+\beta_{3} X_{3} \\
& Y=-4,281+0,448 X_{1}+0,537 X_{2}+ \\
& 0,451 X_{3}
\end{aligned}
$$

Dimana :

$\mathbf{Y}=$ Kinerja organisasi/ SKPD

$\mathbf{a}=$ Konstanta

$\boldsymbol{\beta}_{1}=$ Koefisien regresi
$\mathbf{X}_{\mathbf{1}}=$ Budaya organisasi

$\mathbf{X}_{\mathbf{2}}=$ Kompetensi pegawai

$$
\mathbf{X}_{\mathbf{3}}=\text { Akuntabilitas kinerja }
$$

Dari persamaan tersebut diatas, dapat dijelaskan sebagai berikut :

Koefisien regresi berganda sebesar 0,448 dan 0,537 serta 0,451 mengindikasikan bahwa besaran penambahan tingkat kinerja organisasi (SKPD) setiap pertambahan jawaban responden untuk variabel budaya organisasi, kompetensi pegawai dan akuntabilitas kinerja.

Persamaan regresi berganda $Y=-4,281+0,448 X_{1}+0,537 X_{2}+0,451$ $\boldsymbol{X}_{3}$ digunakan sebagai dasar untuk memperkirakan tingkat kinerja organisasi (SKPD) yang dipengaruhi oleh budaya organisasi, kompetensi pegawai dan akuntabilitas kinerja, kemudian akan diuji apakah valid untuk digunakan dengan hipotesis berdasarkan uji $\mathrm{F}$ (secara simultan) dan uji $\mathrm{t}$ (secara parsial).

\subsubsection{Hasil Uji Hipotesis}

\section{1) Uji F}

Untuk mengkaji pengaruh variabel bebas secara bersama-sama maka digunakan uji F. Pengujian hipotesis ini dilakukan untuk melihat signifikansi pengaruh budaya organisasi, kompetensi pegawai dan akuntabilitas kinerja secara bersama-sama terhadap kinerja organisasi(SKPD). Jika Sig. < 0,05 maka secara simultan semua variabel independen (predictors) mempunyai pengaruh yang bermakna terhadap variabel dependen. Nilai Sig ini digunakan untuk untuk menjawab hipotesa jika $<0,05$ maka $\mathrm{H} 1$ diterima/H0 ditolak. Berikut tabel hasil analisisnya :

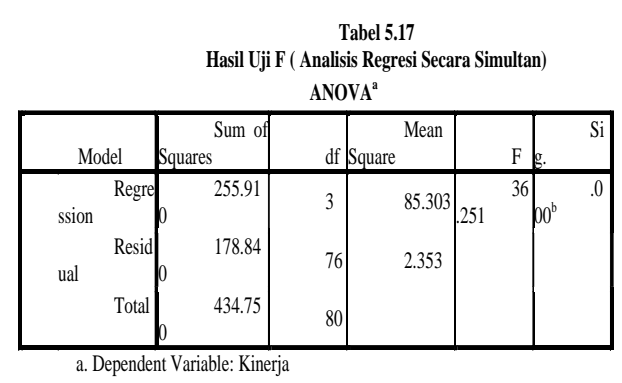


Diketahui bahwa pengaruh variabel bebas secara bersama-sama terhadap variabel dependen dilakukan dengan menggunakan uji F. Berdasarkan tabel 5.17, hasil Uji F Anova $=36.251 \mathrm{dg}$ Sig atau p value Uji F: $0,000<0,05$ Maka ada pengaruh yang signifikan semua variabel independen secara simultan terhadap variabel dependent atau yang berarti $\mathrm{H} 1$ diterima dan $\mathrm{H} 0$ ditolak. Atau berdasar pada hasil perhitungan statistik yang menunjukan nilai Fhitung $=36,251$ dengan nilai Ftabel $=2,16$. Karena $F$ hitung $>F$ tabel ( 36,25 > 2,16) maka HO ditolak dan $\mathrm{Hl}$ diterima, hipotesis yang menyatakan bahwa secara simultan variabel budaya organisasi, kompetensi pegawai dan akuntabilitas kinerja mempunyai pengaruh positif dan signifikan terhadap kinerja SKPD terbukti adanya.

\section{2) Uji t}

Uji t atau uji signifikansi secara parsial adalah untuk mengukur secara terpisah dampak yang ditimbulkan dari masing masing variabel bebas (independent) terhadap variabel tak bebas (dependent). Pengujian secara parsial dilakukan dengan melakukan uji $\mathrm{t}$ hitung, mencari besarnya $\mathrm{t}$ hitung yang akan dibandingkan dengan $t$ tabel. Pengujian $\mathrm{t}$ hitung digunakan untuk mengetahui kualitas keberartian regresi antara tiap-tiap variabel bebas (X) terdapat pengaruh atau tidak terhadap varabel terikat (Y). Jika $\mathrm{t}$ hitung $>\mathrm{t}$ tabel maka H0 ditolak sehingga $\mathrm{H} 1$ diterima. Uji t dilakukan juga dengan melihat taraf signifikansi (p-value), jika taraf signifikansi yang dihasilkan dari perhitungan dibawah 0,025 (karena uji dua sisi maka nilai $\alpha$ 0,05 dibagi 2) hipotesis diterima, sedangkan jika taraf signifikansi hasil hitung lebih besar dari 0,025 maka hipotesis ditolak.

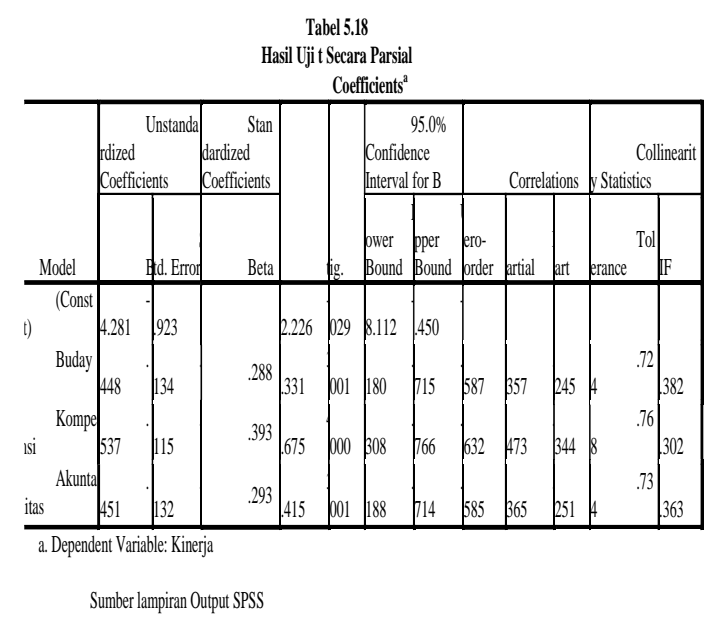

Berdasarkan tabel 5.18 (hasil uji t secara parsial) :

a) Pengujian koefesien regresi budaya organisasi

Pada variabel budaya organisasi, nilai $\quad \boldsymbol{t}$ hitung $=3,331$ dan pada $t$ tabel didapat $\quad t$ tabel $=1,990$, maka Ho ditolak dan Ha diterima karena t hitung $>\mathrm{t}$ tabel. Dengan melihat tabel 5.18 diatas maka taraf signifikansi ( $p$-value) variabel budaya organisasi adalah $0,001<0,025$ sehingga dengan demikian maka budaya organisasi memiliki pengaruh positif dan signifikan terhadap kinerja SKPD.

b) Pengujian koefesien regresi kompetensi pegawai

Pada variabel kompetensi pegawai, nilai $\boldsymbol{t}$ hitung $=4,675$ dan pada $\mathrm{t}$ tabel didapat $\boldsymbol{t}$ tabel $=1,990$ maka $\mathbf{H 0}$ ditolak dan Ha diterima karena $\mathrm{t}$ hitung $>\mathrm{t}$ tabel. Dengan melihat tabel 5.18 diatas maka taraf signifikansi (p-value) variabel kompetensi pegawai adalah $0,001<0,025$ sehingga dengan demikian maka kompetensi pegawai memiliki pengaruh positif dan signifikan terhadap kinerja SKPD.

c) Pengujian koefesien regresi akuntabilitas kinerja

Pada variabel akuntabilitas kinerja, nilai $\quad t$ hitung $=3,415$ pada $\mathrm{t}$ tabel didapat $\boldsymbol{t}$ tabel $=1,990$ maka Ho ditolak dan Ha diterima karena $t$ hitung $>\mathrm{t}$ tabel. Dengan melihat tabel 5.18 diatas maka taraf signifikansi (p-value) variabel akuntabilitas kinerja adalah 
$0,000<0,025$ sehingga dengan demikian maka akuntabilitas kinerja memiliki pengaruh positif dan signifikan terhadap kinerja SKPD.

\section{Pembahasan}

Berdasarkan analisa pengujian diatas, maka dapat penulis paparkan pembahasan untuk menjawab tujuantujuan dalam penelitian ini. Pembahasan hasil penelitian ini sebagai berikut :

1) Pengaruh Budaya Organisasi, Kompetensi Pegawai dan Akuntabilitas Kinerja secara Simultan terhadap Kinerja SKPD

Berdasarkan hasil pengujian secara statisitik dapat terlihat bahwa secara simultan variabel independen berpengaruh terhadap variabel dependen. Pengaruh yang diberikan dari ketiga variabel independen adalah positif artinya semakin tinggi variabel independen maka akan semakin tinggi pula variabel dependennya yakni semakin tinggi kinerja SKPD pada lingkup pemerintah daerah Kabupaten Tabalong.

Hasil pengujian hipotesis telah membuktikan terdapat pengaruh antara variabel independen terhadap variabel dependen, diperolehnya Fhitung sebesar 36,251 dengan taraf signifikansi 0,000. Nilai Fhitung lebih besar dari Ftabel (Fhitung =36,251 > Ftabel $=2,16)$ dan nilai signifikansi lebih kecil dari 0,05. Dengan demikian $\mathrm{H} 1$ diterima dan $\mathrm{HO}$ ditolak. Pengujian statistik membuktikan bahwa variabel budaya organisasi, kompetensi pegawai dan akuntabilitas kinerja mempunyai pengaruh positif dan signifikan terhadap kinerja SKPD lingkup SKPD di Pemda Kabupaten Tabalong.

2) Pengaruh Budaya Organisasi, Kompetensi Pegawai dan Akuntabilitas Kinerja secara Parsial terhadap Kinerja SKPD

a. Pengaruh Budaya Organisasi terhadap Kinerja SKPD

Pengaruh dari budaya organisasi secara parsial dalam penelitian ini yaitu pengaruh budaya organisasi terhadap kinerja SKPD. Berdasarkan data hasil penelitian budaya organisasi merupakan variabel yang menyumbangkan pengaruh paling kecil terhadap kinerja SKPD yakni sebesar $44,8 \%$.

Pengujian hipotesis pengaruh budaya organisasi terhadap kinerja SKPD memperlihatkan bahwa budaya organisasi berpengaruh positif dan signifikan terhadap kinerja SKPD yang ada di lingkup Pemda Kabupaten Tabalong. Maka dapat ditarik kesimpulan bahwa semakin baik budaya organisasi pada sebuah organisasi SKPD maka akan semakin baik pula kinerja SKPD tersebut.

Hasil penlitian ini sesuai dengan yang diungkapkan oleh Ultafakoh Paramitha Dimulyo, Raden Andi Sularso dan Handriyono (2018) dengan judul penelitiannya Pengaruh Budaya Organisasi dan Disiplin Kerja terhadap Motivasi dan Kinerja Karyawan Perbankan, tujuan penelitian ini adalah menganalisis pengaruh budaya organisasi dan disiplin kerja pada motivasi dan kinerja karyawan serta menganalisis pengaruh motivasi terhadap kinerja karyawan. Hasil penelitian menunjukan bahwa Budaya organisasi memiliki pengaruh yang signifikan terhadap motivasi kerja karyawan Bank Jatim Cabang Banyuwangi. Budaya organisasi yang dimiliki menjadi perilaku positif karyawan dalam bekerja yang akan meningkatkan motivasi kerja dan meningkatkan kinerja karyawan.

\section{b. Pengaruh Kompetensi Pegawai terhadap Kinerja SKPD}

Pengaruh kompetensi pegawai secara parsial dalam penelitian ini yaitu pengaruh variabel kompetensi pegawai terhadap kinerja SKPD, berdasarkan data hasil penelitian ini menyumbangkan pengaruh paling besar terhadap kinerja SKPD yakni sebesar 53,7\%. Dalam hal ini menjawab hipotesis penelitian ini, bahwa yang paling dominan mempengaruhi kinerja SKPD adalah kompetensi pegawai dibandingkan dengan variabel budaya organisasi dan akuntabilitas kinerja. 
Pengujian hipotesis pengaruh kompetensi pegawai terhadap kinerja SKPD memperlihatkan bahwa kompetensi pegawai berpengaruh positif dan signifikan terhadap kinerja SKPD yang ada di lingkup Pemda Kabupaten Tabalong. Dalam hal ini variabel kompetensi pegawai merupakan variabel yang paling dominan dalam mempengaruhi peningkatan kinerja SKPD lingkup Pemda Kabupaten Tabalong, kinerja SKPD sangat bergantung pada kompetensi pegawainya, maka dapat ditarik kesimpulan bahwa semakin baik kompetensi pegawai pada sebuah organisasi SKPD maka akan semakin baik pula kinerja SKPD tersebut.

Hasil penelitian ini sejalan dengan penelitian yang dilakukan oleh Acep Dedi Supriadi,Suharto,Sodikin( 2018) dengan judul penelitiannya Pengaruh kompetensi dan budaya organisasi terhadap kinerja karyawan dengan motivasi sebagai variabel mediasi pada Direktorat Jenderal Perimbangan Keuangan-Kementerian Keuangan, Indonesia, Hasil penelitian ini menunjukkan bahwa kompetensi, budaya organisasi, dan motivasi berpengaruh positif dan signifikan pada kinerja karyawan.

\section{c. Pengaruh Akuntabilitas Kinerja terhadap Kinerja SKPD}

Pengaruh akuntabilitas kinerja secara parsial dalam penelitian ini yaitu pengaruh variabel akuntabilitas kinerja terhadap kinerja SKPD, berdasarkan data hasil penelitian ini menyumbangkan pengaruh terhadap kinerja SKPD yakni sebesar 45,1 $\%$. Pengaruh ini tidak terlalu berbeda jauh dengan pengaruh yang dihasilkan oleh variabel budaya organisasi.

Hasil penelitian tentang akuntabilitas seperti yang dilakukan oleh Yosueng Han dan Sounman Hong (2016), penelitian berjudul The impact of Accountability on Organizational Performance in the U.S Federal Government. Hasil penelitian ini menunjukan bahwa tingkat akuntabilitas dimanifestasikan dalam kepegawaian, evaluasi kinerja, dan kompensasi semua positif dan secara signifikan mempengaruhi kinerja organisasi.

\section{Kesimpulan}

Berdasarkan hasil penelitian dan pembahasan yang telah dikemukakan dalam Bab IV, dapat diambil beberapa kesimpulan, yakni :

1) Budaya organisasi berpengaruh positif dan signifikan terhadap kinerja organisasi (SKPD) di Kabupaten Tabalong.

2) Kompetensi pegawai berpengaruh positif dan signifikan terhadap kinerja organisasi (SKPD) di Kabupaten Tabalong.

3) Akuntabilitas kinerja berpengaruh positif dan signifikan terhadap kinerja organisasi (SKPD) di Kabupaten Tabalong.

4) Budaya organisasi, kompetensi pegawai dan akuntabilitas kinerja diduga secara bersama (simultan) berpengaruh positif dan signifikan terhadap kinerja organisasi (SKPD) di Kabupaten Tabalong.

5) Kompetensi Pegawai berpengaruh dominan terhadap kinerja organisasi (SKPD) di Kabupaten Tabalong.

\section{Daftar Pustaka}

Hari Sulaksono, 2015. Budaya Organisasi dan Kinerja. Cetakan Pertama, CV Budi Utama, Yogyakarta

Sofyan Siregar, 2017. Statistik Parametrik untuk Penelitian Kuantitatif . Cetakan Kelima, PT Bumi Aksara, Jakarta

Robbin,SP dan TA Judge. 2008. Perilaku Organisasi. Edisi 12. Terjemahan Salemba Empat, Jakarta

Sobirin A, . 2009. Budaya Organisasi. UPP STM YKPM, Yogyakarta

Noor Fuad, Gafur Ahmad . 2009. Integreted Human Resources Development. Cetakan Kedua . Cetakan PT Grasindo, Jakarta

Hasibuan Malayu SP. 1996. Manajemen Sumber Daya Manusia . Edisi Revisi . Cetakan Bumi Aksara , Yogyakarta

Heru Subaris K, Yasril . 2009. Teknik Sampling Untuk Penelitian 
Cetakan Pertama. Graha ilmu, Yogyakarta

Singgih Santoso . 2018. Menguasai SPSS

Versi 25 . Cetakan Pertama

Penerbit PT Elex Media

Komputindo, Jakarta

Mashal Ahmed, Shaima Safiq, 2014. The Impact of Organizational Culture on Organizational Performance. Jurnal of Management and Business. Volume 14 Issue 3 Version 1.0, Online ISSN 22494588

Mutaqien,Mulasari, 2018. Organizational Performance Improvment Through Culture Control. Jurnal Akuntansi. Volume XXII,pp 210-221

Yousueng Han, Sounman Hong, 2016. The Impact of Accountability on Organizational Performance in the U.S. Federal Government. Jurnal Review of Public Personal Administration. Volume 30,pp 3-23

Acep,Suharto,Sodikin, 2018. The effect of competence and organization culture to employee performance with motivation as the mediation variable in the Directorate General of Fiscal balance-Ministry of Finance, Indonesia. Jurnal Perspective of Financing on Regional Development. Volume 5, No 4

Undang-Undang Nomor 5 Tahun 2014, Tentang Aparatur Sipil Negara, Jakarta. 2014.

Peraturan Pemerintah Nomor 29 Tahun 2014, Tentang Sistem Akuntabilitas Instansi Pemerintah, Jakarta. 2014.

Peraturan Menteri Pendayagunaan Aparatur Negara dan Reformasi Birokrasi Nomor 12 Tahun 2015, Tentang Pedoman atas Implementasi Evalusi SAKIP, Jakarta 2015 